Meta

Journal des tradlucteurs

Translators' Journal

\title{
Curricular Planning
}

\section{Wolfram Wilss}

Volume 22, numéro 2, juin 1977

URI : https://id.erudit.org/iderudit/004611ar

DOI : https://doi.org/10.7202/004611ar

Aller au sommaire du numéro

Éditeur(s)

Les Presses de l'Université de Montréal

\section{ISSN}

0026-0452 (imprimé)

1492-1421 (numérique)

Découvrir la revue

Citer cet article

Wilss, W. (1977). Curricular Planning. Meta, 22(2), 117-124.

https://doi.org/10.7202/004611ar

Ce document est protégé par la loi sur le droit d'auteur. L'utilisation des services d'Érudit (y compris la reproduction) est assujettie à sa politique d'utilisation que vous pouvez consulter en ligne.

https://apropos.erudit.org/fr/usagers/politique-dutilisation/
Cet article est diffusé et préservé par Érudit.

Érudit est un consortium interuniversitaire sans but lucratif composé de l’Université de Montréal, l'Université Laval et l'Université du Québec à Montréal. Il a pour mission la promotion et la valorisation de la recherche. https://www.erudit.org/fr/ 


\section{Curricular Planning}

Curricular issues in the field of translator and interpreter training have recently been the subject-matter of many discussions inside and outside the universities both in Germany and abroad. Nevertheless, it would be a gross exaggeration to say that a satisfactory and practicable solution for all or most of the pertinent problems has been found, and that teaching is geared to a curricular concept based on a broad consensus of expert opinion. Rather the contrary seems to be the case. It is probably legitimate to say that there exists at the moment hardly any other university course with a similar plurality of viewpoints concerning its theoretical, methodical and practical frames of reference.

The wide-spread disagreements over the aims of such a course and the ways and means to implement those aims as down-to-earth curricula have a number of reasons among which the following three seem to be the most important :

1. An intractable obstacle to coherent curricular planning is that each translation bureau and each terminological centre has a specific range of activities and therefore a specific service-function tailored to the specific foreign-language needs of the respective employer. Those graduates of the West-German university schools of translating and interpreting in Germersheim/Mainz, Heidelberg and Saarbrücken who are interested in an in-house (and not free-lance) employment - and this is true of a large majority of our graduates - can apply for a job with those international organizations which have German as an official language, or with the so-called Öffentlicher Dienst (Civil Service) of the Federal Republic of Germany, in particular the internationally-oriented federal agencies in Bonn, or with industrial or commercial enterprises (in particular export/import-intensive firms). It is only natural that the individual employers should differ in their views as to which linguistic and expert qualifications a translator or interpreter must possess in order to be able to fulfil his task in an adequate manner, i.e. to provide his employer with reliable information within a minimum of time so as not to delay the internal flow of communication.

2. A second handicap is (as the author of this article can testify to from his own experience after completing two fairly comprehensive market investigations on the supply/demand relationship in the field of translation/interpretation) that it is very difficult to obtain reliable data on the prospective qualitative and quantitative 
development of the labour market, i.e. on the number of the required junior personnel, on the presumable demand for certain foreign language combinations and expert subjects, etc. In this respect, our students - and the personnel in charge of organizing and adapting established or experimental courses - are therefore rather disadvantageously placed compared with other university departments, e.g. teacher-training, medicine or law, where curricular planning is determined - or at least to some degree determinable - by factors such as the relative strength of age groups (birth-rates), by retirement regulations, by technological and scientific developments, by trade cycles and so on.

3. A third factor, which is now slowly being eliminated, is that a considerable degree of difference of opinion has prevailed among the above-mentioned three schools as to what can and must be achieved within the frame-work of a university course for translators and interpreters. These differences are largely due to historical factors ; that is to say they are consequences of the fact that in the past each school was confronted with specific problems in its attempts to develop a program of true academic standard. This does not mean, however, that each school in the past went off in entirely different directions. There has been a good deal of concurrence, in particular in the basic layout of the teaching programs. The best evidence for this is that some years ago the three schools - on behalf of the West-German Association of University Presidents - worked out a new practicebased and at the same time scientifically oriented course program which, despite marked differences in curricular detail, have created a surprisingly uniform basic structure with the required minimum of inter-school transferability.

The following is an attempt to give the reader a concise survey of the already partially operational - course program as it is envisaged by the Saarbrïcken School of Translating and Interpreting. The whole course is subdivided into two successive study periods, a four-semester basic course (Grundstudium) and a four-semester main course. (Hauptstudium). The Grundstudium, which is completed by a written intermediate examination (Vorprifung), offers a common program for future translators and interpreters; afterwards, with the beginning of the Hauptstudium, the program bifurcates, showing now different centres of gravity according to whether the student later on wants to work as a translator or as an interpreter. Contrary to the linear courses practiced in other schools outside Germany (e.g. in Geneva), which require every student to pass an examination as a translator before he is admitted to interpreter training, Saarbrücken adheres to the "Y-model», because it enables the student to delay his decision on whether he wants to become a translator or an interpreter until the beginning of the fifth semester; on the other hand, it permits the student who wants to become an interpreter and nothing else to finish his course within four years without the time-consuming detour via a translator examination.

\section{A. THE GRUNDSTUDIUM}

Basically the Grundstudium is organized, as far as possible, as a «genneralist » course ; it is planned in such a way as to enable optimal elasticity between different courses (e.g. teacher training, translating, interpreting) without great 
loss of time. The Grundstudium includes two foreign languages (language B and language $\mathrm{C}$ ) with the following course components :

\section{Language Training}

The first two semesters are devoted to intensive language training programs in language $B$ and language $C$. These programs are graded as to « Schulsprachen » (languages learned at grammar schools or secondary schools, usually English and French among German native speakers, English and German among French native speakers, who constitute a fairly large proportion of the entire student population in Saarbrücken). They are based on audio-lingual and audio-visual teaching methods ; audio-lingual methods are employed in Schulsprachen, because audiovisual methods here are too simple (our students come to the School with an already fairly high competence in English and French); on the other hand, in Nichtschulsprachen (in Saarbrücken Dutch, Italian, Russian and Spanish), audiovisual teaching methods are more efficient, because they start from scratch and are optimally in line with the foreign-language teaching and learning postulate of total immersion.

The strong emphasis on foreign-language training in the first two semesters is necessary, because our beginners' mastery of their foreign languages is not adequate for us to start translator training right away. So as to prevent translation classes, which we can offer in a very limited number anyway, from being misused for foreign language learning purposes (e.g. corrective/remedial teaching of grammar or vocabulary), translation teaching is postponed until the third semester. As a result, optimal efficiency of translation classes is guaranteed.

Foreign language training is, of course, particularly intensive in that foreign language which the beginner does not know at all or in which he has so far acquired only rudimentary competence. Our ultimate aim is here to reduce the discrepancy between the competence level in language $B$ and language $C$ as quickly and as thoroughly as possible and to create an approximately comparable basis for the Hauptstudium in both languages. The motivation for this is professional : by teaching our students two foreign languages actively, we want to provide our graduates with the best footing for their future career as translators and/or interpreters.

\section{Translation Exercises}

As of the third semester, translation classes in both directions, foreign language to native language (language A) and vice-versa, gain in importance. All translation classes in the Gundstudium are geared to common language, whereas in the Hauptstudium, as we shall see later on, common language and expert language translation classes are offered side by side. The common-language orientation of translation classes in the Grundstudium is attributable to the fact that each technical-language text contains common language elements but not the conserve. Sound knowledge in translating common-language texts is therefore a condition sine qua non for adequate translation of technical language texts. 


\section{Area or Regional Studies (Landeskunde)}

Area studies in the Grundstudium are conceived as a selective program (Schwerpunktprogramm) consisting of lectures plus discussion groups. Within the framework of the entire course, this program cannot, and should not, achieve more than confronting students with a limited number of present-day subject matters, above all those which are important for the critical understanding of current problems and issues of a foreign country, including political institutions, law, administration, economy, as well as current socio-cultural issues. This is an area-studies program which - so we believe - constitutes a reasonable compromise between an encyclopedic approach which overtaxes both the teaching staff (exclusively native speakers of the respective country) and the students, and an all too narrow specialisation which would not be in harmony with the postulate that the approach to area studies must be functional (in the sense of an auxiliary discipline) rather than academic in the sense of a «Landeswissenschaft », as it is propagated, for exemple, by the Dolmetscher-Institut of the Karl-Marx-Universitat in Leipzig.

\section{Science of Translation}

The program which has so far been described is completed by a course in the science of translation. This course is not devoted to practical learning aims but serves to make thinking and formulation processes in translating and interpreting analytically transparent and to drive home to the students the fact that translating (like interpreting) is a mental, only psycholinguistically, not linguistically explicable operation which basically consists of two phases, a recognition phase in which the translator (and for that matter the interpreter) analyses the original text with regard to its communicative intention, and a reverbalisation phase in which he tries to adequately reproduce the thing-meant of the original text through the medium of target-language sign combinations and sign combination rules. It is the function of the science of translation to investigate the various factors involved in interlingual synchronisation processes, to integrate those therefrom processual regularities (and non-regularities) which then can be exploited for a number of theoretical and practical purposes. All classes in the field of translation science must be organized in such a way as to concentrate on the discussion of language-pairbased translation problems in going from foreign languages to the native language and back. In the Grundstudium, the program in the science of translation is composed of a lecture course (plus tutorials) and a subsequent Proseminar. The lecture course which is offered in the first two semesters, covers a large spectrum of relevant aspects of translating and interpreting; the Proseminar, on the other hand, confronts the students with one specific problem (e.g. the translation of English metaphors into German). Thus it is the preliminary stage to the advanced seminar (Hauptseminar ; see below) which in its turn is an obligatory stage for the dissertation (Diplomarbeit) which again is a precondition for the admission to the final examination. 


\section{Native-Language Course Component}

The Grundstudium is rounded off by native-language classes (in Saarbriicken German and French) which serve to build up a functionally differentiated nativelanguage competence to make it clear to the students that the ability to handle language A efficiently is absolutely imperative for translating and interpreting, and that mastery of language A cannot possibly be looked upon as something finitely achievable, but must be viewed as an infinite process aimed at continuous qualitative and quantitative enlargement of the language A inventory.

\section{B. HAUPTSTUDIUM FOR TRANSLATORS}

The Hauptstudium is intented as a problem-oriented expansion and deepening of the linguistic, translational, regional and translation-scientific knowledge and abilities of our students and consists of the following components :

\section{Translation Exercices}

Emphasis in the Hauptstudium is on the systematic teaching of translating, which now comprises both common-language and technical-language texts. By painstaking analysis and reproduction of a broad spectrum of texts with stylistically and technically incremental degrees of difficulty our students are guided to understand that different types of discourse do not only require different translation strategies, different techniques of segmentation and penetration of the text to be translated, but also different translation equivalence criteria.

\section{Non-Linguistic Complementary Subject (Sachfach)}

Among the curricular problems not yet solved by the Saarbrïcken School is the organisation of the so-called Sachfach, and this is so for two reasons :

a) The Saarbrücken School does not offer its own Sachfach program, but relies on the regular course program of the four faculties of the university. It has transpired over recent years that these programs do not sufficiently cater for the specific needs of our students, who do not intend to become sociologists, psychologists, lawyers, applied mathematicians, etc., but technical translators and interpreters. Our students therefore legitimately demand their own Sachfach programs, which however, for shortage of financial resources have not yet come into existence. There is now one ray of hope, because close cooperations has become feasible as a result of the transformation of the former university of the Saarland into a cooperative type of comprehensive university (Hochschule des Saarlandes) which comprises, among other academic institutions, the former School of Engineering which has declared its support for a combined effort to develop tailor-made courses in the field of technology for all our students.

b) In the second place, the supplementation of the Sachfach program with expert-language translation classes has turned out to be extremely difficult. So far our students could choose as their Sachfach any field fully represented in the university (e.g. International Law, Data Processing, Political Science, Political Economy, Industrial Management, etc.). This rather generous regulation has 
proved to be impractical for organisational and financial reasons. This problem was doubly insoluble because all such translation classes are conducted by a teaching team consisting of a member of our own teaching staff with more or less rudimentary knowledge in the respective field of knowledge, and a member of the teaching staff of the respective faculty with more or less fragmentary foreignlanguage knowledge. Realizing that the teaching capacity of the School in particular and of the university in general is limited, even if we stretch all available resources to the utmost, and that the imbalance between the number of permissible non-linguistic subjects and the number of organizable technical-language translation classes was steadily going up, the School has decided to drastically cut down the number of eligible expert subjects. A new Sachfach program is being worked out by an expert committee which is responsible to the School's Standing Committee on Curricular Planning. To all intents and purposes, it seems certain that the School will have to limit itself to three non-linguistic subjects, technology, industrial management and law; two additional subjects, linguistic and educational science, are still under discussion. The two latter disciplines are of vital interest to the School, because we want to provide our students, who have so far been restricted in their professional activities to translating and interpreting, with a broader range of job opportunities, and because the second additional subject would enable us to create the preconditions for training our own junior teaching staff. Sachfach program and technical-language translation classes are organized on a staggered basis, because one has to have a certain degree of expert knowledge in a certain field before one can sensibly start translating expert-language material.

\section{The Science of Translation}

As indicated above, the science of translation is represented in the Hauptstudium by an advanced seminar which is again focused on language-pair-based problems (e.g. the classification and translation of English participle constructions into German) rather than on general translation-theoretical issues. The subjects for our dissertations are often closely interconnected with the subject-matter of such an advanced seminar; the results of dissertations increasingly have methodical and didactic implications on our course programs and thus provide a feed-back between teaching and research.

\section{HAUPTSTUDIUM FOR INTERPRETERS}

\section{Speech Training, Speech Analysis and Oral Text Reproduction}

The interpreter's main job is the reproduction of oral communication. Provision must therefore be made for a special native-language program which systematically trains would-be interpreters in the situatively adequate manipulation of the phraseology typical of oral communication, as well as in the technique of anticipatory speech analysis and the reproduction of spoken texts.

\section{Consecutive Interpreting}

The interpreter program in the narrower sense of the world begins with exercises in consecutive interpreting including note-taking, a specific technique of 
taking down notes by using special symbols and symbol concatenation signs. In some ways note-taking can be compared to short-hand. In many cases interpreters prefer to develop their own note-taking technique, because they feel that their own system is more economical or more easily adaptable to newly arising subjectmatters. The basic function of this course component is to facilitate the gradual build-up of the competence absolutely imperative for any interpreter, namely to analyse oral communication, to segment complex sense units and to correlate them - co-textually and con-textually - in an appropriate manner.

\section{Simultaneous Interpreting}

For reasons of learning psychology, simultaneous interpreting begins after the student has already mastered consecutive interpreting to some degree. As with consecutive interpreting, simultaneous interpreting from the languages $\mathbf{B}$ and $\mathbf{C}$ to language $\mathrm{A}$ is obligatory, whereas native-language to foreign-language interpreting is obligatory only for language B (optional for language C). Plans are being discussed to drop native-language to foreign-language interpreting entirely ; an argument in favour of such a modification would be that interpreters employed by the international organizations exclusively interpret from the foreign language into their native language; an argument against it would be that the international market for interpreters is largely saturated (or barred for graduates with German as native language; see above) and that employers in the West German Civil Service and in industry insist on active interpreting competence of their interpreters in one foreign language at least.

The Hauptstudium is terminated by the final examination for translators and interpreters ; contrary to the Vorprüfung, the finals consist of a written and an oral part. The question whether the finals for translators should be exclusively written and for interpreters exclusively oral is no longer of any relevance, because any candidate reaching for a university diploma must have the opportunity to compensate an unsatisfactory written examination performance by a better oral examination achievement.

Summarizing, one could say that the Saarbrücken School has tried to develop a curricular concept which may be regarded as forward-looking. We realize, of course, that we are still far away from long-term target of developing a truly interdisciplinary program, and there is reason to assume, if one looks at the national and international scene in the field of the training of translators and interpreters, that other university schools, which realistically assess the present state of affairs, are also fully aware that there is no panacea for our truly challenging problems. Thus, this article is not only meant to offer a description of our curricular planning and our curricular problems, but it should also be regarded as a plea for a dialogue offering a chance for our schools, for the universities possessing such schools, for the responsible ministries of education and for the potential employers of our graduates to cooperate in an unprejudiced manner in the long-term development and practical testing of an internationally competitive 
conceptional framework for the training of university-educated translators and interpreters.

WOLFRAM WILSS

\section{BIBLIOGRAPHICAL REFERENCES}

Bausch, K.-R., J. Klegraf, W. Wilss, The Science of Translation: An Analytical Bibliography. Vol. I (1962-1969) Tübingen 1970, Vol. II (1970-1971) Tübingen 1972, esp. : Sections E (p. 159-160), F (p. 160-161), G (p. 161).

Van Hoof, H., Internationale Bibliographie der Übersetzung - International Bibliography of Translation. München 1973, esp. : Section A.3 Teaching in Translation (p. 198-206). 